\title{
Evaluating the Effects of Sourdough, Bakery Yeast and Sodium Bicarbonate on Texture, Volatile Compounds and Staling of Barbari Bread
}

\author{
Barbari Ekmeğinin Bayatlama ve Uçucu Bileşik Özelliklerine \\ Maya, Fırıncılık Mayası ve Sodyum Bikarbonat Etkisinin \\ Değerlendirilmesi
}

Research Article

Mahboube Zolfaghari, Seyed Mahdi Seyedain Ardebili*, Gholam Hassan Asadi, Kambiz Larijani Department of Food Science and Technology, Tehran Science and Research Branch, Islamic Azad University, Tehran, Iran.

\section{A B S TR AC T}

\begin{abstract}
There are various methods to process dough for bread production. In this study, sourdough, bakery yeast, sodium bicarbonate and a combination of bakery yeast and sodium bicarbonate were used to produce dough of Barbari bread. The structure of the texture of bread, bread staling and volatile compounds of bread samples were analyzed. The results showed that the texture of treated bread samples with a combination of bakery yeast and sodium bicarbonate had less hardness and were stale later. Generally, 33 volatile compounds were observed in this type of bread. Most of these compounds were aldehyde, alcohol, and ketones compounds.
\end{abstract}

Key Words

Bread, sourdough, bakery yeast, volatile compounds.

\section{ÖZET}

— kmek üretimi için hamur hazırlamanın çeşitli teknikleri vardır. Bu çalışmada Barbari ekmeğinin hamurunu E üretmek için maya, fırın mayası, sodyum bikarbonat ve fırın mayasıyla sodyum bikarbonatın bir birleşimi kullanılmıştır. Ekmeğin dokusu, bayat ekmek ve ekmekteki uçucu bileşiklerin yapısı analiz edilmiştir. Sonuçlar, ekmek örneğinin yapısının fırın mayası ve sodyum bikarbonat birleşimiyle daha az sert olduğu ve daha geç bayatladığını göstermektedir. Genel olarak, bu ekmek tipinde 33 farklı uçucu bileşik olduğu görülmüştür. Bu bileşiklerin çoğu aldehit, alkol ve keton bileşikleridir.

\section{Anahtar Kelimeler}

Ekmek, hamur, fırın mayası, uçucu bileşikler.

Article History: Received: Oct 15, 2015; Revised: Nov 19, 2015; Accepted: Nov 20, 2015; Available Online: Dec $30,2015$. DOI: 10.15671/HJBC.20154315987

Correspondence to: S. Ardebili, Department of Food Science and Technology, Islamic Azad University, Tehran, Iran. 


\section{INTRODUCTION}

B arbari is one of the favorite breads in Iran and some Middle East countries. This type of bread is known in other countries like Afghanistan, Turkey, and Arabic countries [1]. Bakery yeast, sourdough and sodium bicarbonate are used to make this kind of bread. Sourdough is a method of fermentation and is made by mixing wheat flour and water without adding starter. The natural microorganisms in flour are used to leaven the dough and are called the mother culture [2]. Sourdough is a system containing lactic acid bacteria and yeast [3].

Another method of leavening is to apply bakery yeast (Saccharomyces cerevisiae). When the bakery yeast is added during preparation of dough, its starch is converted into sugar, alcohol, and carbon dioxide. $\mathrm{CO}_{2}$ bubbles cause the development and leavening of the dough. Sodium bicarbonate is a chemical leavening agent, which has been identified as baking soda and is often used because of low cost, speed up production, and easy transportation [4]. Chemical agents sometimes can leaven the dough regularly and are much better than yeast, because they do not need the long-time activity or environmental conditions to produce gas.

One of the disadvantages of chemical leavening agents is that these agents are not able to create flavor as compared to yeast; so, they can be used with yeast to solve the problem [4]. It seems that these methods have effect on textural characteristics, flavor and the staling process. The effect of bakery yeast and sourdough (with or without lactic acid) has been studied extensively on the flavor and odour of bulky breads [2,5-8].

The connection between sensory characteristics and volatile compounds of bulky breads has been studied [9]. Researchers have studied the effects of sourdough, time, and temperature of fermentation [10] and the amount of yeast, fermentation time, and temperature [11] on the textural parameters of bulky breads. Also, the effect of sourdough is investigated on the rheological characteristics of dough and bulky bread [3], volatile compounds and bread texture [12]. Since studies on flat breads are less compared to bulky breads and the volatile compounds of flat breads have not been identified in Iran and the use of different methods of fermentation to produce the flat bread, the aim of this study was to evaluate the effect of sourdough, bakery yeast, sodium bicarbonate, and combination of sodium bicarbonate and bakery yeast as leavening methods on quality parameters of texture, staling process, volatile compounds, and other sensory characteristics of Barbari bread, which is one of the traditional flat bread which is of interest to Iranian people.

\section{MATERIALS and METHODS Material}

Wheat flour with $82 \%$ extraction, moisture of $14.2 \%$ (wheat bran, w.b), ash of $0.82 \%$, protein of $9.7 \%$, wet gluten of $29 \%$, and falling number of 300-s was prepared by Morvarid Damavand Flour Company, Iran. Instant active dry bakery yeast in powder form was prepared by Fariman Company, Mashhad, Iran. Salt and sodium bicarbonate were obtained from a local supermarket.

\section{Preparation of sourdough}

Sourdough was produced according to this method: $100 \mathrm{~g}$ of wheat flour, $1 \mathrm{ml}$ of vinegar, $2.5 \mathrm{~g}$ of yogurt, and $1 \mathrm{~g}$ of salt were mixed with $60 \mathrm{ml}$ of water, and thereafter, sourdough was fermented at a temperature of 28 to $30^{\circ} \mathrm{C}$ for $20 \mathrm{~h}$.

\section{Formulation and baking bread}

Four types of bread were prepared. Leavening factors were used to make the bread dough, including bakery yeast $(0.5 \% \mathrm{w} / \mathrm{w}$ of the weight based on flour), sourdough $(40 \% \mathrm{w} / \mathrm{w}$ based on the weight of the flour), sodium bicarbonate $(0.5 \% \mathrm{w} / \mathrm{w}$ based on the weight of the flour), and the combination of bakery yeast and sodium bicarbonate in equal proportions $(0.25 \% \mathrm{w} / \mathrm{w}$ based on the weight of the flour), and to prepare the samples of bread dough, water $(60 \% \mathrm{w} / \mathrm{w}$ based on the weight of the flour), salt ( $2 \% \mathrm{w} / \mathrm{w}$ based on the weight of the flour weight), and the dough leavening various agents were mixed in a dough mixer (GLE barhardt, model 11 INIMAT, Germany) at $60 \mathrm{rpm}$ for $15 \mathrm{~min}$. Then, the dough containing sourdough for $4 \mathrm{~h}$ and the dough containing bakery yeast and combination of bakery yeast and sodium bicarbonate for $1 \mathrm{~h}$ were placed at a temperature of 28 to $30^{\circ} \mathrm{C}$ for 
fermentation.

Fermentation has not taken place in the sample containing sodium bicarbonate because of the absence of lactic acid microorganisms or bakery yeast, so this does not need time for fermentation to take place. Then, $650 \mathrm{~g}$ per dough were taken and made round and placed for $15 \mathrm{~min}$ on the table for secondary fermentation to take place on it. Then, the samples were shaped oval with a thickness of $1.2 \pm 0.2 \mathrm{~cm}$, length of $35 \pm 2 \mathrm{~cm}$, and width of $5 \pm 2 \mathrm{~cm}$ and were cooked at $200^{\circ} \mathrm{C}$ for $10 \mathrm{~min}$. Barbari bread treated with bakery yeast, sourdough, sodium bicarbonate and combination of sodium bicarbonate and bakery yeast were marked as $\mathrm{B}_{1}, \mathrm{~B}_{2}, \mathrm{~B}_{3}$, and $\mathrm{B}_{4}$, respectively.

\section{Measuring moisture and $\mathrm{pH}$}

Moisture content and $\mathrm{pH}$ of bread samples were measured according to standard methods AACC number (44-15) and (52-02), respectively [13].

\section{Method of measuring textural characteristics}

Textural characteristics of the samples were studied using a texture analyzer (TA-CT3, Brook field crop, USA). In this experiment, the texture profile analysis test (TPA) and a cylindrical probe (35 $\mathrm{mm}$ diameter) were used in pretest speed and test speed, respectively for 5 and $0.5 \mathrm{~mm} / \mathrm{s}$. Regulated Lod cell was $25 \mathrm{~kg}$. In this method, the size of the bread samples was $15 \times 100 \times 100 \mathrm{~mm}$ and strain deformation was $15 \%$. Hardness, adhesiveness, gumminess, chewiness, cohesiveness and springiness were evaluated.

\section{Method of measuring the staling}

Staling of bread was investigated using differential scanning calorimetry (DSC). $30 \pm 5 \mathrm{mg}$ of the bread samples were weighted and placed in a completely sealed aluminum pan without air. Samples were heated at 25 to $200^{\circ} \mathrm{C}$ and speed of temperature at $5^{\circ} \mathrm{C}$ min-1. Onset point $\left(T_{0}\right)$, peak top $\left(T_{p}\right)$, and enthalpy $(\mathrm{j} / \mathrm{g})$ re-crystallization of starch (Retrogradation) were measured at 24,48 and $72 \mathrm{~h}$ after baking [14].

\section{Volatile compounds}

Volatile compounds were isolated by using the solid-phase micro-extraction method (SPME) and identified by gas chromatography/mass spectroscopy (GC-MS). For each SPME analysis, $10 \mathrm{~g}$ of bread sample, containing both crust and crumb, were introduced into a $50 \mathrm{ml}$ vial with a teflon-lined septum fit at its top. The SPME needle was introduced into the vial, which was then immersed in a water bath at $60^{\circ} \mathrm{C}$. The SPME fibre (2 cm-50/30 mm DVB/Carboxen/PDMS Stable Flex Supelco, Bellefonte, PA, USA) was exposed to the headspace for $60 \mathrm{~min}$. After the end of the extraction time, the fibre was inserted into the injector port of the gas chromatograph (GC) for thermal desorption of the volatiles for 5 min [5]. The GC analyses were performed using a Hewllet Packed model HP 6890 gas chromatograph coupled to a GC-MS HP 5973 mass spectrometer. $\mathrm{HB}_{1}$ column with a $0.25 \mathrm{~mm}$ film thickness, 60 $\mathrm{m} \times 0.32 \mathrm{~mm}$ i.d. was used. The GC temperature program was $60^{\circ} \mathrm{C}$, held for $3 \mathrm{~min}$, then increased by $7^{\circ} \mathrm{C} / \mathrm{min}$ to $230^{\circ} \mathrm{C}$. The carrier gas was helium with a column flow of $2 \mathrm{ml} / \mathrm{min}$. The injector was at $250^{\circ} \mathrm{C}$ in splitless mode. Mass spectra were recorded by electronic impact (EI) at $70 \mathrm{eV}$. The scan mode was used to detect all the compounds in the range $\mathrm{m} / \mathrm{z} 40-300$. The identification of volatile compounds was performed in comparison with standard compounds and MS data obtained with those in Wiley 275.

\section{Sensory characteristics}

Sensory characteristics of Barbari bread were investigated by 10 trained panelists using scoring tests. A piece of bread was given to each panelist to eat and samples were compared in term of shape, down surface and up surface, odor, flavor, color, hardness and softness of texture and chewiness, scoring 1 (poor) to 5 (excellent) [15].

\section{Statistical Analysis}

The experiments were performed in a completely randomized design. All experiments were conducted in triplicates and the mean values and standard deviations were reported. Analysis of variance (ANOVA) was performed and results were separated using the Multiple Ranges Duncan's test $(p<0.01)$ and results of sensory properties were analyzed using the non-parametric Friedman test, using statistical software of Statistical Package for the Social Sciences (SPSS), Version 22; (SPSS, Inc. New Jersey, USA). 
Table 1. pH and moisture of bread samples*.

\begin{tabular}{ccc}
\hline Bread samples & pH & Moisture (\%) \\
\hline $\mathrm{B}_{1}$ & $5.916 \pm 0.015 \mathrm{~b}$ & $33.544 \pm 0.701 \mathrm{~b}$ \\
\hline $\mathrm{B}_{2}$ & $5.206 \pm 0.070 \mathrm{a}$ & $33.407 \pm 2.125 \mathrm{~b}$ \\
\hline $\mathrm{B}_{3}$ & $7.823 \pm 0.159 \mathrm{~d}$ & $29.551 \pm 0.978 \mathrm{a}$ \\
\hline $\mathrm{B}_{4}$ & $7.24 \pm 0.04 \mathrm{c}$ & $32.354 \pm 0.915 \mathrm{ab}$ \\
\hline
\end{tabular}

$\mathrm{B}_{1}$; Barbari bread with bakery yeast, $\mathrm{B}_{2}$; Barbari bread with sour dough, $\mathrm{B}_{3}$; Barbari bread with sodium bicarbonate and $\mathrm{B}_{4}$; Barbari bread with combination of bakery yeast and sodium bicarbonate; $*$ Values are the averages of triplicates \pm standard deviations. Different letters in each column are indicative of significant statistical difference $(P<0.01)$ between the values.

Table 2. Textural Characteristics of the Bread samples.

\begin{tabular}{|c|c|c|c|c|c|c|c|}
\hline $\begin{array}{c}\text { Bread } \\
\text { samples }\end{array}$ & Hardness1 (N) & Adhesiveness (mj) & Hardness $2(\mathrm{~N})$ & Cohesiveness & $\begin{array}{l}\text { Springiness } \\
\quad(\mathrm{mm})\end{array}$ & Gumminess (N) & Chewiness (mj) \\
\hline $\mathrm{B}_{1}$ & $14.610 \pm 1.296 a b$ & $1.646 \pm 0.706 a b$ & $14.095 \pm 1.050 a$ & $0.793 \pm 0.032 a$ & $7.370 \pm 5.014 a$ & $11.622 \pm 1.146 a$ & $81.880 \pm 46.690 a$ \\
\hline $\mathrm{B}_{2}$ & $21.932 \pm 2.00 b$ & $1.800 \pm 0.330 a b$ & $20.989 \pm 2.201 a$ & $0.790 \pm 0.036 a$ & $4.31 \pm 0.113 a$ & $17.336 \pm 2.426 a$ & $74.963 \pm 12.564 a$ \\
\hline $\mathrm{B}_{3}$ & $33.676 \pm 6.940 c$ & $2.426 \pm 0.907 b$ & $32.571 \pm 6.836 b$ & $0.806 \pm 0.015 a$ & $4.340 \pm 0.078 a$ & $27.249 \pm 6.143 b$ & $118.370 \pm 27.308 a$ \\
\hline $\mathrm{B}_{4}$ & $10.650 \pm 2.451 a$ & $0.373 \pm 0.372 a$ & $10.555 \pm 2.410 a$ & $0.863 \pm 0.065 a$ & $7.253 \pm 4.769 a$ & $9.195 \pm 2.088 a$ & $60.133 \pm 23.229 a$ \\
\hline
\end{tabular}

\section{RESULTS AND DISCUSSION Moisture and $\mathrm{pH}$}

The amount of moisture and $\mathrm{pH}$ of samples are shown in Table 1. According to Table 1, sample B2 has the lowest $\mathrm{pH}$ and sample $\mathrm{B} 3$ has the highest $\mathrm{pH}$ value. The low $\mathrm{pH}$ in sample $\mathrm{B} 2$ is due to the use of sourdough to produce bread which is the production of acid by lactic acid bacteria in sourdough. The use of alkaline substance (sodium bicarbonate) increases $\mathrm{pH}$ in sample $\mathrm{B} 4 . \mathrm{pH}$ of bread samples depends on the amount of yeast added, fermentation time, and other additives [16]. The amount of moisture in samples B3 was less than other samples and had significant difference with samples $B_{1}$ and $B_{2}$, but no difference was seen in sample $B_{4}(P \leq 0.01)$.

\section{Textural characteristics of bread samples}

Bread texture is one of the main parameters of quality. Hardness of texture means the loss of soft texture which occurs for two reasons: (i) the low moisture content of the bread, or (ii) retrogradation of starch [17]. If the bread hardness is increased, it reflects the staling of bread [18]. Texture of bread samples' parameters are shown in Table 2 . As shown in the table, there is no significant difference between samples $B_{1}$ and $B_{2}$ and also between $B_{1}$ and $B_{4}$ in term of hardness ( $P \leq 0.01)$

But, hardness is more in $B_{3}$ bread samples as compared to other samples. The reason for this hardness is as a result of the use of sodium bicarbonate alone. Although, sodium bicarbonate can be used as a chemical leavening agent, but when used alone without yeast or leavening agent, it creates unfavorable conditions [4]. In samples $\mathrm{B}_{1}$ and $\mathrm{B}_{4}$ using bakery yeast, hardness is less. Bakery yeast (Saccharomyces cerevisiae) helps to produce enzymes, such as maltase, invertase, and zymase, but is not able to produce hydrolyze proteins. Produced sugar of these enzymes can help to conserve water in the bread crumb.

According to Martin and Hoseney (1991), crosslinking between gluten and starch was formed during baking after swollen of starch and these links are stronger during maintenance of bread [19]. Bakery yeast produce $\mathrm{CO}_{2}$ during fermentation which increases the specific volume of bread [20] and textural characteristics of bread, especially hardness that is partly related to the specific volume of bread and more bread volume, bread will be softer. Hardness in sample $B_{4}$ is less than $B_{1}$, but this difference was not significant ( $P$ $\leq 0.01$ ). 
In the samples of $B_{4}$, the amount of sodium bicarbonate $(0.25 \% \mathrm{w} / \mathrm{w}$ based on the weight of the flour) is added and the $\mathrm{pH}$ reached $7.24 \pm$ 0.40 . This $\mathrm{pH}$ does not have effect on the yeast growth and activity. However, the best $\mathrm{pH}$ for yeast activity is 5.5, but the yeast can adapt and activate in other $\mathrm{pH}$ even at $\mathrm{pH}=3$ to 8 [21].

Also, adding sodium bicarbonate increases the activity of alpha-amylase [22]. Amylase decreases the hardness in the bread due to the reduction of gelatinized power of starch and prevention of crosslinking between gluten and starch [19]. Also in samples B2, it was due to the use of sourdough in their formulation and protolytic activity of lactic acid bacteria leading to decomposition of gluten, and affecting the gluten network and also affecting the characteristics of the final product. Flander et al. showed that a direct link between the uses of sourdough, increase the specific volume and reduce the bread harness [10]. Majzoobi et al. obtained the hardness of Barbari bread from flour particles and various factors as 2.51 to $5.90 \mathrm{~N}$ [23].

Adhesiveness is the required force to overcome the tension between the food ingredients with another material that is in contact with the food (like the mouth, tongue, or even a metal surface) [17]. Among the bread samples studied, samples B3 had the highest amount and samples B4 had the least amount of adhesiveness. Crumb of all the bread in the mouth easily become a ball and is needed to chew; this shape of the texture in the mouth is called cohesiveness. Cohesiveness of bread is controlled by moisture content of the bread and strength of gluten network around the air bubbles [17]. The studied bread samples were not significant in terms of cohesiveness $(P \leq 0.01)$.

Majzoobi et al. obtained the cohesiveness of Barbari bread made from different flour particle size and different factors as 0.91 to 1.01 [23]. Springiness is the ability to recover its original shape after removal of required force to deform. Chewiness is the work needed to chew a solid food until it is ready to devour. Gumminess is the force required to break a semi-solid material ready to devour and is obtained by multiplying hardness and adhesiveness [2426]. Bread samples were not significantly different in terms of the amount of springiness, gumminess and chewiness $(P \leq 0.01)$.

\section{Staling of samples bread}

The mean values of enthalpy, onset point $\left(T_{0}\right)$ and peak top ( $\left.T_{p}\right)$ of bread samples regardless of the time of maintenance is summarized in Table 3. According to the results, the enthalpy of samples $B_{1}$ and $B_{2}$ were significantly different, but no significant difference was observed in samples $B_{3}$ and $B_{4}(P \leq 0.01)$. Average enthalpy of samples $B_{3}$ was higher than other samples (447.38 \pm 86.150 $\mathrm{J} / \mathrm{g}$ ) and sample $\mathrm{B}_{4}$ was lower than the rest of the studied samples $(237.57 \pm 78.9 \mathrm{~J} / \mathrm{g})$. High enthalpy reflects more energy to melt the retrogradation crystals of starch [27]. So, $B_{3}$ samples showed more staling as compared to other.

According to the report of Al-Dmoor et al. (2009), by adding sodium bicarbonate, the maximum gelatinized starch is made up. Sodium bicarbonate cannot ideally produce $\mathrm{CO}_{2}$ alone, but also should be used with bakery yeast or weak acid leavening agents [4]. In fact, the use of sodium bicarbonate with yeast increases amylase activity [22]. As a result, amylose is broken before cooking which is responsible for retrogradation of the starch and becomes too simple sugars which is consumed by yeast during fermentation; therefore, the mean values of enthalpy and therefore staling is reduced in these bread [28]. The mean values of $T_{0}$ in samples $B_{1}$ and $B_{2}$ had no statistically significant difference, but in samples $B_{1}, B_{2}$ and $B_{3}$, significant difference was observed. Also, in samples $B_{4}$, a significant difference was observed and in samples $B_{2}$ and $B_{4^{\prime}}$ there was no significant difference $(P \leq 0.01)$.

Samples $B_{2}$ and $B_{4}$ showed significant difference in terms of mean values of $T_{p}$, but with samples $B_{1}$ and $B_{3}$, they are significant. The highest values of $T_{0}$ and $T_{P}$ are seen in samples $B_{3}$ and $B_{1}$ is the least amount of samples. Table 4 shows the average enthalpy values, $T_{0}$ and $T_{p}$ in three time (24, 48 and $72 \mathrm{~h}$ after baking), regardless of the type of treatment (fragmentation method). As shown in the table, the average enthalpy values are significantly different in the three times studied $(P \leq 0.01)$, and increased over time, 
Table 3. Enthalpy variations, Peak and onset point temperatures of bread samples regardless of the time of maintenance .

\begin{tabular}{cccc}
\hline Bread samples & $\Delta \mathrm{H}(\mathrm{j} / \mathrm{g})$ & $\left.\mathrm{T}_{\mathrm{p}}{ }^{\circ} \mathrm{C}\right)$ & $\mathrm{T}_{0}\left({ }^{\circ} \mathrm{C}\right)$ \\
\hline $\mathrm{B}_{1}$ & $266.994 \pm 76.135 \mathrm{~b}$ & $113.353 \pm 8.732 \mathrm{a}$ & $69.458 \pm 8.266 \mathrm{a}$ \\
\hline $\mathrm{B}_{2}$ & $275.132 \pm 78.939 \mathrm{~b}$ & $118.081 \pm 2.419 \mathrm{~b}$ & $75.225 \pm 5.086 \mathrm{ab}$ \\
\hline $\mathrm{B}_{3}$ & $447.385 \pm 86.150 \mathrm{c}$ & $125.648 \pm 3.822 \mathrm{c}$ & $81.133 \pm 4.25 \mathrm{c}$ \\
\hline $\mathrm{B}_{4}$ & $237.574 \pm 78.939 \mathrm{a}$ & $117.851 \pm 3.192 \mathrm{~b}$ & $76.405 \pm 4.360 \mathrm{~b}$ \\
\hline
\end{tabular}

$\Delta \mathrm{H}$ : Recrystallization enthalpy showing retrogradation, $\mathrm{T}_{\mathrm{p}}$ : peak temperature, $\mathrm{T}_{0}$ : onset point Temperature. $\mathrm{B}_{1} ; \mathrm{Barbari}$ bread with bakery yeast, $B_{2} ;$ Barbari bread with sour dough, $B_{3} ;$ Barbari bread with sodium bicarbonate and $B_{4} ;$ Barbari bread with combination of bakery yeast and sodium bicarbonate; *Values are the averages of Triplicates \pm Standard deviations. Different letters in each column are indicative of significant statistical difference $(P<0.01)$ between the values.

Table 4. The average enthalpy values, $T_{p}$ and $T_{o}$ in three time $(24,48$ and $72 \mathrm{~h}$ after baking), regardless of the type of treatment.

\begin{tabular}{cccc}
\hline Storage time $(\mathrm{h})$ & $\Delta \mathrm{H}(\mathrm{j} / \mathrm{g})$ & $\left.\mathrm{T}_{\mathrm{p}}{ }^{\circ} \mathrm{C}\right)$ & $\mathrm{T}_{0}\left({ }^{\circ} \mathrm{C}\right)$ \\
\hline 24 & $244.313 \pm 82.359 \mathrm{a}$ & $117.581 \pm 5.705 \mathrm{a}$ & $75.746 \pm 4.480 \mathrm{ab}$ \\
\hline 48 & $273.636 \pm 87.495 \mathrm{~b}$ & $114.817 \pm 6.846 \mathrm{a}$ & $70.858 \pm 8.556 \mathrm{a}$ \\
\hline 72 & $402.365 \pm 96.014 \mathrm{c}$ & $123.802 \pm 3.916 \mathrm{~b}$ & $80.061 \pm 3.360 \mathrm{~b}$ \\
\hline
\end{tabular}

which represent an increase of retrogradation and staling of bread. Salehifar et al. found similar results [14]. Some reactions occurred between gelatinized starch granules and gluten networking during storage of bread, leading to a reduction in kinetic energy and therefore the hardness of bread is increased. The mean values of $T_{0}$ and $T_{P}$ in 24 and $48 \mathrm{~h}$ after baking together showed no significant difference, but the mean difference values of $T_{0}$ in 48 and $72 \mathrm{~h}$ after cooking was significant. Also, average value of $T_{P}$ in 24 and $48 \mathrm{~h}$ after baking with its value at $72 \mathrm{~h}$ showed a significant difference $(P \leq 0.01)$.

\section{Volatile compounds}

Volatile compounds of bread samples are shown in Table 5. Generally, 34 volatile compounds were identified by gas chromatography-mass spectrometry (GC-MS), including alcohols, ethers, aldehydes, ketones, and carbonyl. Number of volatile compounds identified in samples $B_{4^{\prime}} B_{3^{\prime}}$ $B_{2}$, and $B_{1}$ were 22, 20, 16 and, 23, respectively. One of the most important identified compounds is alcohols, such as ethanol and 3-methyl-butanol. These substances are observed in samples B4, $B_{2}$, and $B_{1}$. Ethanol is one of the most important compounds caused by yeast ( $S$. cerevisiae) fermentation and lactic acid bacteria.
The percent of this compound (RPA) in samples $B_{2}$ is greater than the other samples. The amount of ethanol is destroyed during cooking (Rehman et al., 2006). 3-Methyl-1-butanol is an iso-alcoholic that arises through Erhlich pathway cycle in yeast cells [29]. The existence of this compound in samples B2 is for this reason, 'that during sourdough fermentation, amino acids caused by proteolytic enzymes bacteria is produced' which are the precursor of iso-alcoholic [2].

Wu et al. obtained a high percentage of ethanol and 3-methyl-butanol in breads from sourdough [12]. Also, Birch et al. obtained high percentage of 3-methyl-butanol in a yeast breads. One of the most important compounds found in breads are aldehyde and ketone compounds [8]. Of the aldehyde compounds, 3-methyl-butanal and 2-methyl-butanal are seen more than other aldehydes in the bread. The percentage of these compounds is more in $B_{1}$ and then $B_{4}$ samples as compared to other samples.

3-Methyl-butanol like Iso-alcohol can occur through the Ehrlich pathway in yeast cells [29]. 2-Methyl-butanal is obtained as the Maillard reaction of amino acid isoleucine during cooking. Hexanal is found in all samples. The percentage of this compound is more in $\mathrm{B}_{2}$ samples as compared 
to other samples. This combination was seen in results of Wu et al. and Plessas [12,30]. Decanal is also aldehyde found in samples $B_{1}$.

Hexanal and decanal can also be produced by lipids oxidation found in flour by lipoxygenase enzyme [8]. Of the ketone compounds detected were 2, 3 butanedione or diacetyl (in samples $B_{1}$ $\mathrm{B}_{2^{\prime}}$ and $\mathrm{B}_{3}$ ), 2, 2- butanone (in all samples), 2, 3 pentanedione (in sample $B_{2}$ ) and 2-propanone (in samples $\mathrm{B}_{2}$ and $\mathrm{B}_{3}$ ).

The main source of ketones is the Maillard reaction. In addition, 2, 3 butanedione is produced by decarboxylation of hydroxy acids out of the yeast cells; yeast cells are responsible for producing such acids (Lilly et al., 2000). Ketone compound concentrations in samples $B_{1}$ are more than the rest of the samples. This compound was also observed in the results of Birch et al. and Plessae et al. $[8,30]$.

The most important identified ester compounds are ethyl acetate. The composition is observed in samples $B_{1}, B_{2}$ and $B_{4}$. The percent of ethyl acetate in samples $B_{1}$ and $B_{4}$ produced by bakery yeast is more. Ethyl acetate occurs from the reaction of alcohols and acids. In walls of yeast alcohol, acetyltransferase enzyme activities are also produced in the fermentation time [31]. In sample B2, lactic acid bacteria heterofermentative in sourdough produce ethyl acetate $[2,32]$. This compound has also been found in the results of Plessas et al.

Acetic acid is the detected compounds in samples of $B_{2}, B_{1}$ which is higher in $B_{2}$. Lactic acid bacteria in sourdough lead to an increase in the amount of acid in samples $B_{2}$. Acetic acid production improved dough quality during leavening. Lactic acid bacteria in sourdough produce lactic acid and the ration of lactic acid to acetic acid is highly effective in the final flavor bread [2]. Unfortunately, in this study, lactic acid was not identified with the use of GC-MS. According to Table 5, volatile compounds have also been identified in the breads.

In samples of $\mathrm{B}_{2}$ and $\mathrm{B}_{3^{\prime}}$ these compounds were higher. The existence of these compounds is due to the Maillard reaction at high temperature during cooking [33]. In addition to the above compounds, aromatic hydrocarbons and aliphatic were also identified in the studied samples. Aliphatic hydrocarbons were detected in samples $B_{3}$. In results of Wu et al., some aliphatic hydrocarbons were observed [12].

Aromatic hydrocarbons were observed in samples $B_{1}$ and then $B_{4}$. The origin of these compounds can contain additives, such as benzoyl peroxide added to bleach flour [34]. Some of aromatic compounds have been observed in the results of Wu and et al [12]. Other identified compounds can be noted as toluene. This compound is produced by fuel in the oven during baking. This compound has been observed in all the four samples.

Limonene is a terpene compound which is observed in samples of $B_{1}, B_{3^{\prime}}$ and $B_{4}$. This compound is observed in some of the results of some researches $[8,12]$. In general, the number of volatile compounds to produce odour was seen in samples $B_{4}$ more than other samples. Most of the compounds were identified in samples $B_{1}, B_{4}$ which uses bakery yeast to produce the dough are ethanol, 3-methyl-butanol, ethyl acetate, 3-methyl-butanal and 2-methyl-butanal.

The percent of these compounds is used more in samples $B_{1}$ as compared to samples $B_{4}$ which uses high yeast to produce the dough. Most compounds identified in samples B2 which uses sourdough in the production of dough are ethanol, hexanal, 2-methylfuran, and acetic acid. Since the formulation of $B_{3}$ samples yeast or sourdough have not been used, so many products that were obtained during fermentation in the sample were not found or observed with low rates.

\section{Sensory characteristics}

Sensory characteristics of bread (shape, up surface, down surface, color, texture, chewiness, odour, and flavor) were scored by panelist group. Results of these scores are shown in Table 6. Bread samples were not significantly different in terms of appearance ( $P \leq 0.01$ ), but were significantly different in terms of other characteristics ( $P \leq$ 0.01). As shown in Table 6, $B_{1}$ samples are superior 
Table 5. Headspace analysis of volatile compounds of bread samples.

\begin{tabular}{|c|c|c|c|c|c|}
\hline & & Relative & peak area & $\%$ & \\
\hline $\mathrm{RT}(\min )$ & Compound & B1 & B2 & B3 & B4 \\
\hline \multicolumn{6}{|c|}{ Alcohols } \\
\hline 4.06 & Ethanol(Ethyl alcohol) & 10.55 & 8.881 & nd & 9.28 \\
\hline 6.16 & 3-Methyi-1-butanol & 11.61 & 8.148 & nd & 4.70 \\
\hline \multicolumn{6}{|c|}{ Aldehydes } \\
\hline 4.36 & Isobutyraldehyde & 2.22 & nd & 2.48 & 2.25 \\
\hline 4.38 & 2-Methyl-propanal & 3.17 & 2.25 & nd & 2.12 \\
\hline 4.97 & 3-Methyl-1-butanal & 7.03 & 3.28 & 2.39 & 6.60 \\
\hline 5.06 & 2-Methyl-butanal & 7.52 & 3.54 & 2.75 & 5.49 \\
\hline 6.79 & N-Hexanal & 2.041 & 12.32 & 10.05 & 8.92 \\
\hline 15.82 & Decanal & 2.23 & nd & nd & $\mathrm{n}$ \\
\hline \multicolumn{6}{|c|}{ Ketones } \\
\hline 4.15 & 2-Propanone & nd & 2.33 & 6.97 & nd \\
\hline 4.49 & 2,3-Butanedione(Diacetyl) & 5.42 & 2.34 & nd & 2.17 \\
\hline 4.55 & 2-Butanone & 1.52 & 2.43 & 6.47 & 2.28 \\
\hline 5.30 & 2,3-Pentanedione & nd & 2.69 & nd & nd \\
\hline
\end{tabular}

\section{Esters}

4.67

Ethyl acetate(Acetic ether)

13.23

4.41

nd

9.12

Furans

\begin{tabular}{lccccc}
5.02 & Furan-2-methyl & 2.48 & 14.94 & 19.50 & 6.57 \\
5.18 & Furan-3-methyl & nd & 4.01 & nd & nd \\
\hline 5.51 & Furan-2-ethyl & nd & 2.64 & 4.71 & 1.73 \\
11.17 & Furan-2-penthyl & 1.83 & 2.38 & 9.02 & 5.06 \\
7.24 & Furfura & 0.92 & nd & nd & 2.02
\end{tabular}

Aliphatic hydrocarbons

$\begin{array}{llcccc}4.23 & \text { Pentane } & \text { nd } & 1.17 & 5.40 & \text { nd } \\ 5.62 & \text { Heptane } & \text { nd } & \text { nd } & 3.91 & 2.66 \\ 7.20 & \text { n-Octane } & \text { nd } & 3.86 & 3.64 & 1.41 \\ 16.16 & \text { Dodecane } & \text { nd } & \text { nd } & 4.75 & 1.52 \\ 19.8 & \text { Pentadecane } & 1.73 & 2.38 & 1.14 & \text { nd }\end{array}$


Table 5. The Composition of the Essential Oils of Anthemis coelopoda var. coelopoda. (continue)

\begin{tabular}{|c|c|c|c|c|c|}
\hline \multicolumn{6}{|c|}{ Aromatic hydrocarbons } \\
\hline 6.44 & Benzen-methyl(Toluene) & 4.50 & 4.85 & 8.06 & 4.95 \\
\hline 8.04 & Benzen-1,4-dimethyl & 2.96 & nd & nd & nd \\
\hline 8.41 & Benzen-1,3-dimethyl & 1.51 & nd & nd & 3.79 \\
\hline 8.91 & Benzen-1,2-dimethyl & 2.22 & nd & nd & 1.12 \\
\hline 10.50 & Benzen-1-ethyl-2-methyl & nd & nd & nd & 0.92 \\
\hline 11.99 & $\begin{array}{l}\text { Benzen-1-methyl-3-(1- } \\
\text { methyl ethyl) }\end{array}$ & 6.38 & nd & nd & nd \\
\hline \multicolumn{6}{|c|}{ Organic acids } \\
\hline 4.37 & Acetic acid & 1.12 & 7.76 & nd & 1.92 \\
\hline \multicolumn{6}{|c|}{ Terpenes } \\
\hline 12.22 & Limonene & 2.62 & nd & 4.30 & 3.61 \\
\hline 13.74 & BETA-Thujene & 5.56 & nd & nd & nd \\
\hline
\end{tabular}

RT: Retention time ; nd; not detected; $\mathrm{B}_{1}$; Barbari bread with bakery yeast, $\mathrm{B}_{2}$; Barbari bread with sour dough, $\mathrm{B}_{3}$; Barbari

Table 6. Score of sensory evaluation of breads.

\begin{tabular}{ccccccccc}
\hline $\begin{array}{c}\text { Bread } \\
\text { samples }\end{array}$ & $\begin{array}{c}\text { Up } \\
\text { surface }\end{array}$ & $\begin{array}{c}\text { Down } \\
\text { surface }\end{array}$ & Colour & Texture & Chewiness & Odour & Flavour & Total \\
\hline $\mathrm{B}_{1}$ & 1 & 1 & 2 & 2 & 2 & 1 & 1 & 1 \\
\hline $\mathrm{B}_{2}$ & 3 & 2 & 3 & 3 & 3 & 2 & 3 & 3 \\
\hline $\mathrm{B}_{3}$ & 4 & 3 & 4 & 4 & 4 & 4 & 4 & 4 \\
\hline $\mathrm{B}_{4}$ & 2 & 1 & 1 & 1 & 1 & 3 & 2 & 2 \\
\hline
\end{tabular}

$\mathrm{B}_{1}$; Barbari bread with bakery yeast, $\mathrm{B}_{2}$; Barbari bread with sour dough, $\mathrm{B}_{3}$; Barbari bread with sodium bicarbonate and $\mathrm{B}_{4} ;$ Barbari bread with combination of bakery yeast and sodium bicarbonate.

than other samples in term of up surface, odour, and flavor and $\mathrm{B}_{3}$ sample is in fourth rating in term of surface, color, texture, chewiness, odour, and flavor (Table 6).

In samples $B_{4}$ and $B_{1}$ due to the use of bakery yeast, fermentation was done and material for producing flavor of fermentation and yeast activity took place. In the formulation of $B_{1}$ as compared to $B_{4}$ samples, more yeast is used $(0.5 \% \mathrm{w} / \mathrm{w}$ based on the weight of the flour) and as shown in Table 5, the percentage of aldehyde and alcohol compounds in samples $B_{1}$ is more than B4 samples. Samples B4 in terms of down surface, color, texture, and chewiness were dominated to other samples (Table 6). Measuring hardness and chewiness samples using a texture analyzer is less in B4 samples as compared to other samples (Table 2), although this difference is not significant $(P \leq 0.01)$.

\section{CONCLUSION}

Examining bread samples in terms of texture, staling process and sensory characteristics showed that bread containing bakery yeast are softer in term of texture and longer stale. Examining the volatile compounds in breads showed that although the number of detected volatile compounds in the samples produced with a combination of bakery yeast and sodium bicarbonate is more, but the percentage of alcohol and aldehyde compounds responsible for the odour and flavor is more in samples produced 
by yeast (because of the use of more bakery yeast in the formulation). So, these samples were scored in high rank by panelist group in term of odour and flavour. The use of sourdough is the preferred method for the production of bread. But sourdough should be enriched with homofermentative and heterofermentative lactic acid bacteria to create a better flavor and texture.

\section{References}

1. M.A. Majzoobi, M. Farahnaky, Sh. Agah, Properties and Shelf-life of Part-and Full-baked Flat Bread(Barbari) at Ambient and Frozen Storage. Journal of Agricalture Science and Technology, 13 (2011) 1077-1090.

2. S.U. Rehman, A.Paterson, J.R. Piggott, Flavour in sourdough breads: A review, Trends in Food Science and Technology, 17 (2006) 557-566.

3. D. Gocmen, A.N. Inkaya, E. Aydin, Flat Breads, Bulgarian Journal of Agricultural Science, 15 (4) (2009) 298-306.

4. G.G. Bellido, G. Martin, M.G. Scanlon, J.H. Page, Measurement of dough specific volume in chemically leavened dough systems, Journal of Cereal Science, 49(2009) 212-218.

5. S. Plessas, A. Bekatorou, J. Gallanagh, P. Nigam A.A. Koutinas, C. Psarianos, Evolution of aroma volatiles during storage of sourdough breads made by mixed cultures of Kluyveromyces marxianus and Lactobacillus delbrueckii ssp. bulgaricus or Lactobacillus helveticus, Food Chemistry, 107 (2008) 883-889.

6. S. Plessas, A. Fisher, K. Koureta, C. Psarianos, P.Nigam, A.A. Koutinas, Application of Kluyveromyces marxianus, Lactobacillus delbrueckii ssp. bulgaricus and L. helveticus for sourdough bread making, Food Chemistry, 106 (2008) 985-990.

7. G. Styger, D. Jacobson, F.F. Bauer, Identifying genes that impact on aroma profiles produced by Saccharomyces cerevisiae and the production of higher alcohols, Applied Microbiology and Biotechnology, 91 (2011) 713-730.

8. A.N. Birch, M.A.Petersen, A.S. Hansen, The aroma profile of wheat bread crumb influenced by yeast concentration and fermentation temperature, LWTFood Science and Technology, 50 (2013) 480-488.

9. S.P. Heenan, J.P. Dufour, N. Hamid, W. Harvey, C.M. Delahunty, Characterisation of fresh bread flavor: relationships between sensory characteristics and volatile composition, Food Chem, 116 (2009) 249-257

10. L. Flander, T. Suortti, K. Katina, K. Poutanen, Effects of wheat sourdough process on the quality of mixed oat-wheat bread, LWT-Food Science and Technology, 44 (2011) 656-664.

11. M. Gomez, B. Oliete, V. Pando, F. Ronda, P.A. Caballero. Effect of fermentation conditions on bread staling kinetics, Eur Food Res technol, 226 (2008) 1379-1387.

12. C. Wu, R. Liu, W. Huang, P.R. Duarte, F. Wang, Y. Yao, Effect of souedough fermentation on the quality of Chinese northern-style steamed breads, Journal of Cereal Science, 56 (2012) 127-133.

13. AACC. Approved Methods of Analysis of the American Association of Cereal Chemists, (2000) St.Paul,MN.

14. M. Salehifar, S.M. Seyyedain, M.H. Azizi, Changes in Wheat Starch Crystallinity During Staling of Flat Breads: Effects of Protein on Retrogradation, Journal of Food Biosciences and Technology, 1 (2011) 25-32.

15. S.A. Hematian, Y.F. Tabatabaei, G.A. M. Davoodi, S.A. Mortazavi, M. Karimi, J.S. H. Razavizadegan, A. Pourfarzad, Staling and Quality of Iranian Flat Bread Stored at Modified Atmosphere in Different Packaging. World Academy of Science, Engineering and Technology, 41 (2010) 422-427.

16. S. Movahed, G.H. Rooshenas, H. Chenarbon. Evaluation of the effect of yeast-salt method on dough yield, bread yield and organoleptic properties iranian lavash bread, Annals of Biological Research, 3 (2012) 595-600.

17. S.P. Cauvain, Improving the texture of bread, Woodhead Publishing Ltd and CRC Press LLC (2004).

18. C.L. Tsai, J. Sugiyama, M.M. ShibataKokawa, K. Fujita, M. Tsuta, H. Nabetani, T. Araki, Changes in the texture and viscoelastic properties of bread containing rice porridge during storage, Bioscience, Biotechnology, Biochemistry, 76 (2012) 331-335.

19. M.L. Martin, R.C. Hoseney, A mechanism of bread firming, Role of starch hydrolyzing enzymes, J. Cereal. Chem., 68 (1991) 503-507.

20. A. Ali, A. Shehzad, M.R. Khan, M.A. Muhammad, M. R. Amjid, Yeast, its types and role in fermentation during bread making process, A. Pak. J. Food., SCl, 22 (2012) 171-179.

21. J.T. Holmes, R.C. Hoseney, Chemical leavening: Effect of $\mathrm{pH}$ and certain ions on breadmaking properties, Cerial Chemistry, 64 (1987) 343-348.

22. H.M. Al-Dmoor, H. Herzallah Saqer, M. Al-Lruwaili. Effect of sodium bicarbonate, ascorbic acid and salt on the $\alpha$-amylase, gelatinization and yeast activity in the production of flat bread, Journal of Food, Agriculture \& Environment, 7 (2009) 155 - 158 .

23. M.A. Majzoobi, M. Farahnaky, Z. Nematolahi, M. Mohammadi Hashemi, M.J. Taghipour Ardakani, Effect of different levels and particle sizes of wheat bran on the quality of flat bread, Journal of Agricalture Science and Technology, 15 (2013) 115-123.

24. G. Jaworska, E. Bernas, Effects of pre-treatment, freezing and frozen storage on the texture of Boletus edulis (Bull: Fr.) mushrooms, International Journal of Refrigeration, 33 (2010) 877-885.

25. R.P.F. Guine, M.J. Barrocab, Effect of drying treatments on texture and color of vegetables (pumpkin and green pepper), Food and Bioproducts Processing, 90 ( 2012) 58-63.

26. L. Chen, U.L. Opera, Approaches to analysis and modeling texture in fresh and processed foods - A review, Journal of Food Engineering, 119 (2013) 497507. 
27. P.D. Ribotta, A.L. Bail. Thermo-physical assessment of bread during staling. J. LWT Food Sci Technol, 40 (2007) 879-884.

28. J.M. Deman, Principle of food chemistry. Aspen Publishers, Inc, Gaithersburg, Maryland, chap 4, 1999

29. L.A. Hazelwood, J.M. Daran, A.J.A. van Maris, J.T. Pronk, J.R. Dickinson, The Ehrlich pathway for fusel alcohol production: A century of research on Saccharomyces cerevisiae metabolism, Applied and Environmental Microbiology, 74 (2008) 2259-2266.

30. S. Plessas, A. Alexopoulos, I. Mantzourani, A. Koutinas, C. Voidarou, E. Stavropoulou, E. Bezirtzoglou, Application of novel starter cultures for sourdough bread production. Anaerobe, 17 (2011) 486-489.

31. M. Lilly, M.G. Lambrechts, I.S. Pretorius, Effect of increased yeast alcohol acetyltransferase activity on flavor profiles of wine and distillates, Applied and Environmental Microbiology, 66 (2000) 744-753.
32. S. Procopio, F. Qian, T. Becker, Review paper: Function and regulation of yeast genes involved in higher alcohol and ester metabolism during beverage fermentation, European Food Research and Technology, 233 (2011) 721-729.

33. J.K. Parker, G.M. Hassell, D.S. Mottram, R.C. Guy. Sensory and instrumental analyses of volatile generated during the extrusion cooking of oat flour, Journal of Agricultural and Food Chemistry, 48 (2000) 3497-3506

34. E.J.Mulders, The odor of white bread. IV. Quantitative determination of constituents in the vapour and their odour values, Zeitschrift für LebensmittelUntersuchung und-Forschung, 151 (1973) 310-317. 
